\title{
Profile of vitamin D receptor gene polymorphism TaqI in patients with periodontitis
}

\author{
NURLINDAH HAMRUN ${ }^{1}$, MUHAMMAD RUSLIN $^{2}$, ERNI MARLINA $^{3}$, SRI OKTAWATI $^{4}$, \\ TAKASHI SAITO ${ }^{5}$, ANDI SITTI HAJRAH YUSUF ${ }^{2}$ and KENG-LIANG OU ${ }^{6,7}$
}

\begin{abstract}
Departments of ${ }^{1}$ Oral Biology, ${ }^{2}$ Oral and Maxillofacial Surgery, ${ }^{3}$ Oral Medicine, ${ }^{4}$ Periodontology, Faculty of Dentistry, Hasanuddin University, Makassar, South Sulawesi 90425, Indonesia; ${ }^{5}$ Division of Clinical Cariology and Endodontology, Department of Oral Rehabilitation, School of Dentistry, Health Sciences University of Hokkaido, Hokkaido 060-8586, Japan;

${ }^{6}$ Department of Dentistry, Taipei Medical University-Shuang Ho Hospital, New Taipei City 235;

${ }^{7}$ Biomedical Technology R\&D Center, China Medical University Hospital, Taichung 404, Taiwan, R.O.C.
\end{abstract}

Received December 5, 2021; Accepted February 11, 2022

DOI: $10.3892 /$ br.2022.1518

\begin{abstract}
The present study aimed to assess the incidence of the vitamin D receptor (VDR) gene polymorphism TaqI in patients with periodontitis, and the potential association of this polymorphism with the severity of the disease. This was a case-controlled study, which included 162 adults divided into two groups as follows: Case group (81 patients diagnosed with periodontitis) and control group (81 patients without periodontitis). Venous blood was obtained from each sample from which DNA was extracted. The gene polymorphism was determined using restricted fragment length polymorphism-PCR and DNA sequencing to identify endonuclease restrictions in exon 9 (TaqI). The data were analyzed using an independent samples t-test. $V D R$ gene polymorphisms were detected in periodontitis cases with TT $(86.4 \%)$, $\mathrm{Tt}(12.4 \%)$ and $\mathrm{tt}(1.2 \%)$ genotypes. DNA sequencing confirmed a change in the sequence of the VDR gene nucleotides in patients with periodontitis. The data indicated that the severity of periodontal tissue damage may be influenced by changes in the nucleotide sequence.
\end{abstract}

\section{Introduction}

Periodontitis is one of the most common inflammatory diseases affecting the tissues supporting teeth and it is characterized by progressive resorption of the alveolar bone (1-3). Periodontitis is also one of the primary causes of loss of teeth in adults, and it can affect an individual's quality of life if left untreated (4-6). Periodontitis is initiated by bacterial plaque

Correspondence to: Dr Nurlindah Hamrun, Department of Oral Biology, Faculty of Dentistry, Hasanuddin University, J1. Perintis Kemerdekaan KM 10, Makassar, South Sulawesi 90425, Indonesia

E-mail: lindahamrun@unhas.ac.id

Key words: vitamin D receptor, periodontal disease, DNA amplification, TaqI, genotype on the tooth surface and can be caused by multiple factors, such as an imbalance of periodontal pathogens, host immunity and other environmental, local and systemic factors $(7,8)$. The majority of studies on this topic have emphasized on the role of genetic factors in disease pathogenesis, and on their ability to influence the unique reaction that characterizes the susceptibility of each individual $(1,5)$. Approximately $50 \%$ of the clinical severity of periodontitis may be associated with host genetics $(3,8)$. However, the genetic effects may differ among different ethnicities due to the diversity of the subjects in a population $(3,7)$. Therefore, understanding of the pathophysiology of this disease from a genetic standpoint is essential for its early detection and diagnosis.

Over the past decade, considerable efforts have been made to identify the influence of various genetic factors, such as genes that code for IL-1 (9), TNF- $\alpha$ (10), IL-10 (11), IL-4 (12), IL-4 receptor- $\alpha$ (13), Fc $\gamma$ receptor (14), CD-14 (15) and the vitamin D receptor (VDR). The genetic predispositions associated with these genes are considered to affect the severity of different diseases $(16,17)$. VDR, in particular, is a promising candidate in periodontitis since it affects both bone metabolism and immunological function $(4,18)$. This receptor is present in various cell types and can act as a transcriptional regulator (2). It is located on chromosome $12 \mathrm{q}$ and has 14 exons, 6 of which are located on the 5 'region that is not translated $(1 \mathrm{a}-1 \mathrm{f})(7,18)$. The untranslated 3 'region of the $V D R$ gene comprises a polymorphism cluster in TaqI, ApaI and BsmI $(19,20)$. If the function of VDR is affected by the polymorphisms of the $V D R$ gene, the contribution of these variants is considered critical for the pathogenesis of systemic diseases related to bone tissues, such as periodontal disease $(19,20)$.

Several studies have attempted to elucidate an association between the presence of VDR gene polymorphisms and the pathogenesis of certain diseases. A series of characterized $V D R$ gene polymorphisms, including those for the FokI, ApaI, TaqI and BsmI genes have been previously reported $(2,3,5)$. To date, an association has been found between the susceptibility to periodontal disease and a certain number of single-candidate gene polymorphisms (21). Other studies have also shown a connection between periodontal disease 
and vitamin D levels $(2,22,23)$. Although extensive evidence has been obtained, the majority of the studies were only focused on the investigation of the association between periodontitis and the $V D R$ gene polymorphism (2,21-23). In the present study, DNA sequencing and restricted fragment length polymorphism (RFLP)-PCR analysis were used to further examine the changes in nucleotide arrangement of the $V D R$ gene. The identification of genetic variants linked to the increased susceptibility to certain diseases may be key to the development and advancement of preventive medicine. Therefore, the aim of the present study was to investigate possible correlations between the VDR gene polymorphisms, specifically in exon 9 (TaqI), and the severity of periodontitis. This study was a case-controlled study and the subjects were recruited from a Makassar-based population in Indonesia.

\section{Materials and methods}

Study population and data collection. The present study was a case-controlled study including patients who were enrolled at the Periodontology Department of the Dental Hospital, Hasanuddin University, Indonesia. The study protocol was approved by the Ethics Committee for Biomedical Research in Humans, Faculty of Medicine, Hasanuddin University (approval no. 0189/H.04.8.4.5.31/PP36-KOMETIK/2010, approval date 04/06/2010). The current study was performed in accordance with the Declaration of Helsinki (24). In total, 162 individuals were recruited, and they were divided into two groups: Case group, patients diagnosed with periodontitis (14 males and 67 females) and the control group, healthy patients without periodontitis ( 38 males and 43 females). The median age of the case group was 38 years (age range 25-60) and the median age of the control group was 34 years (age range 22-60). Determination of the sample size was based on the Lemeshow formula for the case-controlled study design. The actual odd ratio (OR) estimate was $\sim 2$. Consideration of $\mathrm{OR}=2$ has been used in previous research studies; an OR of 2 obtained in these previous studies suggested that samples with VDR gene polymorphisms were $2 \mathrm{x}$ more likely to suffer from chronic periodontitis than those without VDR gene polymorphisms. Thus we used this as minimum standard to calculate our sample size $(25,26)$. Since the number of populations was infinite (unknown) P2* $=0.5$ was used with a value of 0.05 . The anticipated rate was $10 \%$ and the power of the test was 0.842 .

The diagnostic criteria for the case group included patients diagnosed with periodontitis based on the New Classification of Periodontal Disease (2018) (27). The periodontitis stage in the present study was divided into three categories as determined previously (24). It was based on the clinical attachment loss (CAL) and probing pocket depth (PPD): Stage I, CAL 1-2 $\mathrm{mm}$ and maximum PPD $\leq 4 \mathrm{~mm}$; stage II, CAL 3-4 mm and maximum PPD $\leq 5 \mathrm{~mm}$; and stages III and IV, CAL $\geq 5 \mathrm{~mm}$ and $P P D \geq 6 \mathrm{~mm}$. The diagnostic criteria for the control group were healthy patients without periodontitis, which was defined by the absence of clinically detectable inflammation in the gingiva, such as an intact periodontium without a gingival recession and CAL, 'salmon' or 'coral pink' in color, firm in consistency and firmly attached to the underlying alveolar bone. The subjects that were suitable for the present study were included in the case and the control groups and were provided with the necessary information regarding the research procedure. They were asked to sign the relevant informed consent form for their agreement in participating in the study. The recruitment of the patients was performed for 1 year by two allocated researchers. The first researcher selected patients from the medical record and completed the information in the research form regarding age, sex, ethnicity, occupation, medical history and history of drugs used. Subsequently, a Professor in the Department of Periodontology performed the clinical examination for the diagnosis of periodontal disease and suggested whether or not each patient was suitable for inclusion in the study.

Inclusion and exclusion criteria. The inclusion criteria were: Indonesian patients, age range of 25-60 years, and had at least 20 teeth. The patients who exhibited 2 interproximal sites with $C A L \geq 2 \mathrm{~mm}$, and 6 interproximal sites with $\mathrm{PPD} \geq 4 \mathrm{~mm}$ were also included. The exclusion criteria were the following: Patients with systemic diseases, such as diabetes, tuberculosis, hepatitis or human immunodeficiency virus, as well as patients with smoking habits or had used prosthetics. Moreover, patients who were pregnant and/or breastfeeding were also excluded from the study.

Clinical examination. Patients who met the inclusion criteria received a comprehensive dental examination and a complete research chart was recorded. It is well established that important clinical signs of periodontitis include poor to moderate scores in the oral hygiene index-simplified (OHI-S), PPD and CAL $(27,28)$, therefore these clinical signs were used to evaluate their influence on the incidence of VDR gene polymorphisms. Initially, the number of caries teeth, the number of edentulous and the OHI-S score (29) were assessed. Subsequently, scaling was performed on all subjects using an ultrasonic scaler. The clinical examination was performed to evaluate the PPD and the level of CAL. The measurements of PPD were made at 6 sites on each tooth according to the charting form used in the Department of Periodontology. The largest value from 6 tooth surfaces in each tooth was obtained for analysis. CAL was measured based on the distance from the cementoenamel junction to the base of the pocket. For analysis, interdental $\mathrm{CAL}$ at the site of the greatest loss was taken.

Laboratory analysis. Venous blood (0.5-1 ml) samples were obtained from all subjects in both groups for laboratory analysis. The DNA from the peripheral leukocytes was extracted and purified using the Boom method (30). The analysis was performed in the Laboratory of Immunology and Molecular Biology, Faculty of Medicine, Hasanuddin University (Makassar, Indonesia). The gene polymorphisms were determined based on endonuclease restriction in exon 9 of the examined $V D R$ gene using RFLP-PCR and direct sequencing.

Amplification by PCR. In all subjects, VDR gene polymorphisms were detected in exon 9 using the following specific primers: Forward, 5'-CTGGGGAGCGGGGAGTATGAA GGA-3' and reverse, 5'-GGGTGGCGGCAGCGGATGTA-3' (https://omim.org/entry/601769). DNA amplification was conducted for RFLP using the TaqI restriction enzyme. The PCR amplification was performed using 32 cycles, consisting 
of denaturation for $1 \mathrm{~min}$ at $94^{\circ} \mathrm{C}$, annealing for $1.5 \mathrm{~min}$ at $59^{\circ} \mathrm{C}$, and extension for $2 \mathrm{~min}$ at $72^{\circ} \mathrm{C}$. Following the completion of 32 cycles, the samples were heated at $72^{\circ} \mathrm{C}$ for $7 \mathrm{~min}$. The amplification products were analyzed by agarose gel electrophoresis.

RFLP-PCR analysis. Following amplification, $5 \mu 1$ PCR amplification products and $2 \mu \mathrm{l}$ loading buffer were mixed and loaded onto $1.5 \%$ agarose gels along with ethidium bromide. The gel was soaked in a container with Tris borate EDTA buffer, and subsequently, electrophoresis was performed at a steady voltage of $80 \mathrm{~V}$ for $1 \mathrm{~h}$. The gel was removed and observed under UV light. The fragment bands observed at different distances from the sample indicated genotypic differences of the VDR gene polymorphism. The differences were marked with the letter $t$ (a restriction area is present) or the letter T (no restriction area is present). The genotypes based on the bands of the agarose gels were classified as follows: i) TT: Absence of fragment sizes at 1,398 bp; ii) Tt: Presence of fragment sizes at (946 $+452 \mathrm{bp}$ ) and 1,398 bp and iii) tt: Presence of fragment sizes at $946 \mathrm{bp}$ and $452 \mathrm{bp}$.

DNA sequencing. In all obtained samples, direct sequencing was performed by Macrogen, Inc. Sequencing confirmed the changes in the nucleotide base arrangement in exon 9 of the $V D R$ gene.NCBI BLAST was used to analyze the sequencing results.

Statistical analysis. SPSS version 11.5 (SPSS, Inc.) was used for data analysis. The mean \pm SD were calculated for all descriptive variables. An independent samples t-test was performed to detect phenotypic differences in subjects with periodontitis. $\mathrm{P}<0.05$ was considered to indicate a statistically significant difference. Hardy-Weinberg equilibrium was verified manually using a standard calculation formula (31).

\section{Results}

Distribution and characteristics of the subjects. In total, the data were collected for 162 patients from the Dental Hospital, Hasanuddin University. The age was known for all 162 patients. The detailed characteristics of the subjects are shown in Table I. Based on the independent samples t-test, it was found that both edentulous and OHI-S were significantly higher is the case group compared with the control groups $(\mathrm{P}<0.05$; Table I). This difference indicated that patients with periodontitis exhibited worse oral hygiene than healthy patients without periodontitis.

VDR gene polymorphism. The VDR gene polymorphism consists of the following three genotypes: TT (1 band), tt ( 2 bands), and Tt (3 bands) (Fig. 1A and B). The TT genotype $(1,398 \mathrm{bp})$ indicated no fragment sizes, whereas fragment sizes of 946, 452 and 1,398 bp were obtained for the Tt genotype and fragment sizes of 946 and 452 bp for the tt genotype. The genotype distribution of the VDR gene in the case and control groups is highlighted in Table II. It was noted that the case group exhibited a higher percentage of the TT genotype $(86.4 \%)$ compared with either the $\mathrm{Tt}(12.3 \%)$ or the $\mathrm{tt}(1.2 \%)$ genotypes. The control group had a TT genotype percentage of $98.8 \%$, a Tt genotype percentage of $1.2 \%$, and an absence of the tt genotype. Both case and control groups exhibited a genotype distribution within the Hardy-Weinberg equilibrium $\left[\mathrm{p}^{2}+2 \mathrm{pq}+\mathrm{q}^{2}=1 ;(0.96)^{2}+2(0.96)(0.04)+(0.04)^{2}=1.0016\right]$.

The comparison between the $V D R$ genotype of the subjects with periodontitis was based on the mean value of OHI-S, PPD and CAL (Table III). The results confirmed that the mean of OHI-S was higher for the patients with periodontitis and the TT genotype (mean score, 2.71) than that of the patients with periodontitis and the $\mathrm{Tt} / \mathrm{tt}$ genotype (mean score, 2.12). However, the difference was not statistically significant (P>0.05). Both the PPD status and CAL were higher for the $\mathrm{Tt} / \mathrm{tt}$ genotype (PPD mean score, 5.14; CAL mean score, 4.41) compared with those of the TT genotype (PPD mean score, 3.52; CAL mean score, 2.80). Both of these parameters indicated significant differences, with P-values of 0.006 and 0.001 , respectively.

Polymorphism analysis of the VDR gene by sequencing. DNA sequencing confirmed a change in the sequence of the VDR gene nucleotides (Fig. 2). The data indicated the sequencing results of the three genotypes. The nucleotide sequence for the $\mathrm{tt}$ genotype at codon 352 was altered compared with that of the initial sequence of AGGTCGA (Fig. 2A and B); the final sequence was: AGGCCGA (Fig. 2C). This indicated a nucleotide substitution from T to C (GTC to GCC) due to the change in the amino acid valine (coded by GTC) to alanine (coded by GCC).

\section{Discussion}

The aim of the present study was to identify the presence of the $V D R$ gene polymorphisms in patients with periodontitis (32). Subsequently, the $V D R$ gene polymorphism was assessed as a risk factor associated with periodontitis between patients with periodontitis and healthy subjects (33). The present study examined the change in the nucleotide sequence of the $V D R$ gene to explore the potential association of the VDR gene polymorphism with the severity of the disease. Limited studies have been performed utilizing DNA sequencing for the identification of genetic variants that are linked to susceptibility to periodontitis. In addition, to the best of our knowledge, the present study is the first study in this context conducted in Indonesia.

Current research conducted in the field of periodontology has particularly focused on the influence of genetic factors on individual susceptibility to periodontitis (34-36). The tendency for early-onset periodontitis can be inherited with either an autosomal recessive or autosomal dominant trait $(37,38)$. In the present study, it was found that the frequency of the $\mathrm{Tt}$ and $\mathrm{tt}$ genotypes ( $t$ allele) was lower than that of the TT genotype (T allele) in both periodontitis and healthy subjects. This result is reasonable owing to the fact that the population in Makassar, Indonesia, as a part of the Asian race, has a minor presentation of the $\mathrm{Tt}$ and $\mathrm{tt}$ genotypes in the $V D R$ gene. A similar result was noted in a study by Zmuda et al (39) that reported a frequency of the $\mathrm{Tt}$ and $\mathrm{tt}$ genotypes of only $2 \%$ in Asians, $5 \%$ in African Americans and $17 \%$ in Caucasians. In accordance with these findings, two previous studies conducted by Sun et al (37) and 
Table I. Clinicopathological characteristics of the recruited cohort.

\begin{tabular}{|c|c|c|c|c|c|}
\hline \multirow[b]{2}{*}{ Parameters } & \multicolumn{2}{|c|}{ Case, $n=81$} & \multicolumn{2}{|c|}{ Control, $\mathrm{n}=81$} & \multirow[b]{2}{*}{ P-value } \\
\hline & Mean & SD & Mean & SD & \\
\hline Age, year & 38.9 & 9.24 & 37.61 & 11.82 & 0.443 \\
\hline Height, $\mathrm{cm}$ & 155.53 & 6.55 & 157.33 & 7.33 & 0.101 \\
\hline Weight, $\mathrm{kg}$ & 55.46 & 6.45 & 56.19 & 9.22 & 0.618 \\
\hline Body mass index, $\mathrm{kg} / \mathrm{m}^{2}$ & 22.47 & 2.9 & 23.18 & 3.4 & 0.936 \\
\hline Edentulous & 2.48 & 2.69 & 1.06 & 1.07 & $<0.001^{\mathrm{b}}$ \\
\hline Caries & 2.17 & 2.3 & 2.04 & 1.69 & 0.673 \\
\hline Oral hygiene index-simplified & 2.63 & 0.96 & 2.29 & 0.69 & $0.011^{\mathrm{a}}$ \\
\hline Probing pocket depth, mm & 4.54 & 1.27 & - & - & \\
\hline Stage I $(\leq 4 \mathrm{~mm})$ & 4 & 0 & & & \\
\hline Stage II $(\leq 5 \mathrm{~mm})$ & 5 & 0 & & & \\
\hline Stage III/IV ( $\geq 6$ mm) & 7.2 & 1.98 & & & \\
\hline Clinical attachment loss, $\mathrm{mm}$ & 3.02 & 1.48 & - & - & \\
\hline Stage I (1 to $2 \mathrm{~mm})$ & 2 & 0 & & & \\
\hline Stage II ( 3 to $4 \mathrm{~mm}$ ) & 3.55 & 0.54 & & & \\
\hline Stage III/IV ( $\geq 6$ mm) & 5.91 & 1.16 & & & \\
\hline
\end{tabular}

${ }^{\mathrm{a}} \mathrm{P}<0.05,{ }^{\mathrm{b}} \mathrm{P}<0.001$.

Tachi et al (25) also reported that the t allele was present in only $4 \%$ of a Chinese ethnic group and in $11 \%$ of a Japanese ethnic group. Moreover, a small distribution of the $t$ alleles in the Asian race was also noted by Wang et al (40); only in $5 \%$ of the population examined.

The differences in the frequency of the genotypes or alleles in a population can be explained by the following concept: All polymorphisms begin as mutations occurring as a result of DNA damage. As the frequency of the allele increases in the population, the mutation is converted to a polymorphism $(41,42)$. The difference in the allele frequencies between ethnicities tends to be influenced by evolutionary processes and genetic traits of a single population. Similar association studies regarding $V D R$ polymorphisms and periodontal disease have been performed in other ethnic populations and races $(34,43,44)$. A study by Borges et al (45) reported an OR of 4.57 for the association between $V D R$ and periodontitis in a Brazilian population. In 2004, de Brito et al (26) also reported that the genotype and haplotype of the VDR gene polymorphism may be associated with the incidence of periodontal disease. The corresponding OR values were 2.41 and 4.32, respectively. Similarly, Brett et al (46) demonstrated an association between $V D R$ gene polymorphism and periodontitis in the Caucasian race. Similarly, Tachi et al (25) reported an OR value as high as 2.3 in the Japanese population.

In our previous study, an OR value of 12.57 was noted indicating that subjects with $V D R$ gene polymorphisms exhibited a 12.57-fold higher probability of suffering from periodontitis than those without $V D R$ gene polymorphism (33). This is expected considering that the $V D R$ gene is involved in various processes ranging from bone metabolism to the regulation of the immune response. The fundamental etiology of periodontitis is inflammation caused by bacterial infection, which promotes alveolar bone resorption; therefore, the VDR gene appears to be an optimal candidate for predicting periodontitis susceptibility. Previously published studies demonstrated that $V D R$ plays an important role in trabecular bone compared with its role in cortical bone $(26,46)$. Moreover, the variation in the $V D R$ allele is responsible for the variation in bone mineral density (BMD) $(26,46) . V D R$, which is involved in controlling calcium and phosphate concentrations in the blood, is disrupted by the presence of variations in the DNA sequence or the presence of polymorphisms, resulting in a decrease in BMD across the body, including the mandible and maxilla (47). A decrease in jaw bone density will increase the alveolar porosity by altering the trabecular pattern, which will eventually increase the bone resorption rate following the invasion of periodontal pathogens $(46,48)$.

In the current study, the clinical features of periodontal tissue damage accompanying periodontitis were investigated by examining the periodontitis phenotype. The results indicated that patients with periodontitis who had the $\mathrm{Tt} / \mathrm{tt}$ genotype exhibited a higher severity of periodontal tissue damage than those with the TT genotype. It was assumed that the $\mathrm{Tt} / \mathrm{tt}$ genotype of exon 9 of the $V D R$ gene affected mRNA stability or decreased the expression levels of mRNA of osteoblast-associated genes. This would decrease osteoblast function and increase osteoclast function, thereby leading to severe alveolar trabecular bone resorption. These findings are in accordance with a previous study conducted by Sun et al (37) who demonstrated that the presence of the $\mathrm{t}$ allele in the VDR TaqI may be a risk indicator for the susceptibility to early-onset periodontitis. Tachi et al (25) supported the findings of Sun et al (37) by demonstrating that the incidence of the TaqI polymorphism was associated with the susceptibility of developing aggressive periodontitis. In 

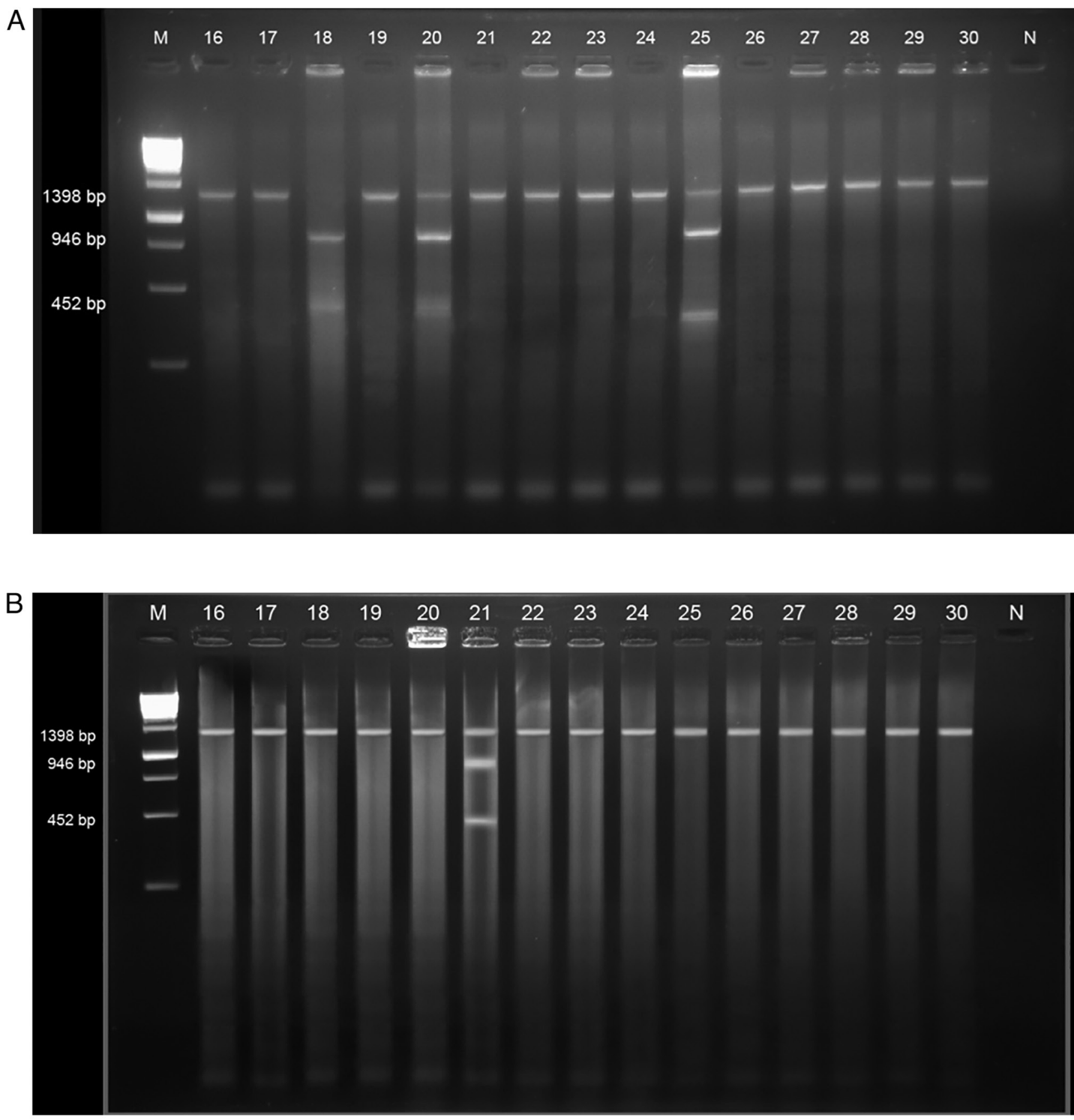

Figure 1. VDR gene polymorphism. Restricted fragment length polymorphism-PCR in the (A) case group and (B) control group. VDR, vitamin D receptor.

another study, the incidence of the homozygous $(\mathrm{tt})$ genotype of TaqI in patients with osteoporosis was significantly higher in the osteoporosis group compared with that of the control group (18).

In addition to assessing the incidence of the $V D R$ gene polymorphism, the present study detected a change in the sequence of the nucleotides corresponding to the amino acid valine. The nucleotide substitution in exon 9 (TaqI) of the $V D R$ gene results in the conversion of valine to alanine in patients with periodontitis. Another published study evaluated the levels of $V D R$ gene expression in intron 8 and demonstrated that the detection of ApaI C/T single nucleotide polymorphism \#rs731236 in patients with chronic periodontitis was an important factor that was often overlooked in the prevention of this disease (43). Accumulated evidence from the previously published systematic review and meta-analysis showed that $V D R$ is a biological effector of vitamin $\mathrm{D}$ that controls bone metabolism and inflammatory gene expression (5). Accordingly, in another review, it was also found that genetic polymorphisms could modify gene expression or function. Therefore, they may affect biological pathways and the susceptibility of the subjects to a variety of diseases (49). The likely explanation for these observed associations is to assume the existence of a truly functional sequence variation to a different part of the gene, which is, to a certain extent, linked to an allele of the anonymous polymorphism explored $(25,49)$. In the present study, it was assumed that the nucleotide change would likely affect the level of $V D R$ gene expression, which subsequently influences the translation rate of the protein or causes certain changes in RNA stability and translation. This increased the susceptibility of subjects with the $t$ allele to a low bone density phenotype. The present study showed that patients with the tt genotype had a higher PPD $(8 \mathrm{~mm})$ than those of the patients with the $\mathrm{Tt}$ and TT genotypes. Therefore, the findings of the present study emphasize on the assumption that patients with the tt genotype are susceptible to decreased bone density or decreased immune system function. Unfortunately, since this was not fully addressed in the current research, it is recommended to analyze these findings in future studies. 
Table II. Vitamin D receptor gene genotype frequency in the case and control groups.

\begin{tabular}{lrrrrr}
\hline & \multicolumn{2}{c}{ Case } & & \multicolumn{2}{c}{ Control } \\
\cline { 2 - 3 } \cline { 5 - 6 } Genotype & $\mathrm{n}$ & $\%$ & & $\mathrm{n}$ & $\%$ \\
\hline $\mathrm{TT}$ & 70 & 86.42 & & 80 & 98.77 \\
$\mathrm{Tt}$ & 10 & 12.35 & & 1 & 1.23 \\
$\mathrm{tt}$ & 1 & 1.23 & & 0 & 0 \\
Total & 81 & 100 & & 81 & 100 \\
\hline
\end{tabular}

Table III. Comparison of the Vitamin D receptor genotype in patients with periodontitis based on OHI-S, PPD and CAL.

\begin{tabular}{lllllll}
\hline & \multicolumn{2}{c}{$\begin{array}{c}\text { TT genotype, } \\
\mathrm{n}=70\end{array}$} & & \multicolumn{2}{c}{$\begin{array}{c}\text { Tt/tt genotype, } \\
\mathrm{n}=11\end{array}$} \\
\cline { 2 - 3 } Parameter & Mean & SD & & Mean & SD & P-value \\
\hline OHI-S & 2.71 & 0.95 & & 2.12 & 0.93 & 0.06 \\
PPD & 3.52 & 1.49 & & 5.14 & 2.98 & $0.006^{\mathrm{a}}$ \\
CAL & 2.8 & 1.26 & & 4.41 & 2.06 & $0.001^{\text {a }}$ \\
\hline
\end{tabular}

${ }^{\text {a }}<<0.001$. OHI-S, oral hygiene index-simplified; PPD, probing pocket depth; CAL, clinical attachment loss.

It is important to note that the present study has certain limitations such as the small sample size and consisted of individuals from a single center. Therefore, additional research is required to identify the specific pathogenesis of this disease and the functional significance of the polymorphisms of the $V D R$ gene.

In conclusion, the findings of the present study suggested that the VDR gene polymorphism was associated with periodontitis in the Makassar-based population. Indirect evidence confirms that the severity of periodontal tissue damage may be a consequence of the presence of the $t$ allele or the $t$ genotype.

\section{Acknowledgements}

We would like to thank Professor Bahruddin Talib (Department of Prosthodontics, Faculty of Dentistry, Hasanuddin University, Makassar, Indonesia) and Professor Budu (Department of Ophthalmology Faculty of Medicine, Hasanuddin University) for their valuable scientific support, as well as Professor Burhanuddin Daeng Pasiga (Department of Dental Public Health, Faculty of Dentistry, Hasanuddin University) for their expert support in data analysis.

\section{Funding}

The present study was supported by the Ministry of Research, Technology, and Higher Education of the Republic of Indonesia (grant no. 1109/D3/PL/2010).
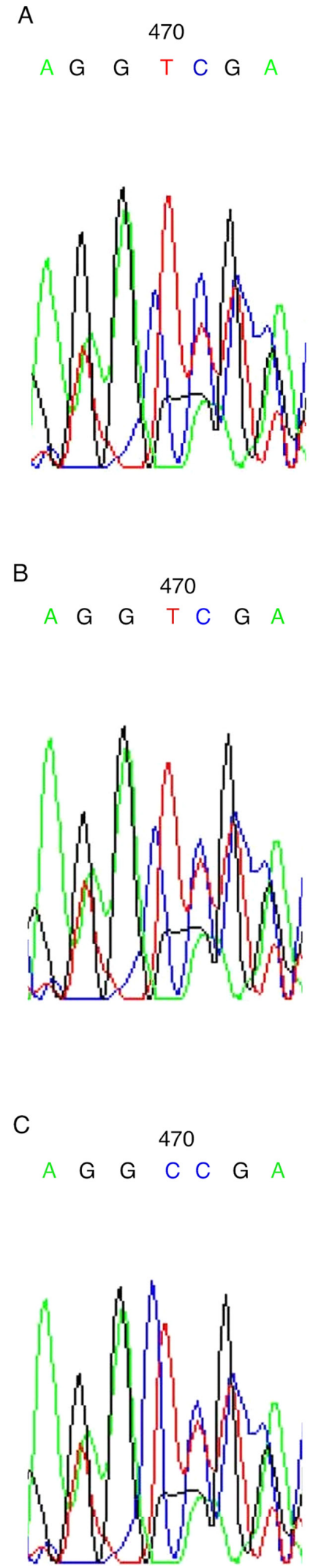

Figure 2. DNA sequencing of the VDR genotype. Sequencing of the (A) TT, (B) $\mathrm{Tt}$ and (C) $\mathrm{tt}$ genotype. VDR, vitamin $\mathrm{D}$ receptor.

\section{Availability of data and materials}

The datasets used and/or analyzed during the present study are available from the corresponding author on reasonable request. 


\section{Authors' contributions}

$\mathrm{NH}, \mathrm{SO}$ and EM conceived and designed the study, and wrote the original draft of the manuscript. MR and ASHY analyzed and interpreted the data, and edited the manuscript. TS and KLO assisted in the design of the study, curated the data, and reviewed and edited the manuscript. All authors have read and approved the final manuscript. NH, SO and MR confirm the authenticity of all the raw data.

\section{Ethics approval and consent to participate}

The present study was approved by the Ethics Committee for Biomedical Research in Humans, Faculty of Medicine, Hasanuddin University (approval no. 0189/H.04.8.4.5.31/PP36-KOMETIK/2010). All patients in the case and control groups provided informed consent prior to the initiation of the study. The experimental procedures were based on the Declaration of Helsinki.

\section{Patient consent for publication}

The patients provided written informed consent for the publication of any data and/or accompanying images.

\section{Competing interests}

The authors declare that they have no competing interests.

\section{References}

1. Heidari Z, Moudi B and Mahmoudzadeh-Sagheb HJ Immunomodulatory factors gene polymorphisms in chronic periodontitis: An overview. BMC Oral Health 19: 29, 2019.

2. Nazemisalman B, Vahabi S, Sabouri E, Hosseinpour S and Doaju S: Association of vitamin D binding protein and vitamin $\mathrm{D}$ receptor gene polymorphisms in Iranian patients with chronic periodontitis. Odontol 107: 46-53, 2019.

3. Gago EV, Cadarso-Suarez C, Perez-Fernandez R, Burgos RR, Mugica JD and Iglesias CS: Association between vitamin D receptor FokI. polymorphism and serum parathyroid hormone level in patients with chronic renal failure. J Endocrinol Invest 28 : $117-121,2005$

4. Khammissa R, Ballyram R, Jadwat Y, Fourie J, Lemmer J and Feller LJ: Vitamin D deficiency as it relates to oral immunity and chronic periodontitis. Int J Dent 2018: 7315797, 2018.

5. Wan QS, Li L, Yang SK, Liu ZL and Song N: Role of Vitamin D receptor gene polymorphisms on the susceptibility to periodontitis: A meta-analysis of a controversial issue. Genet Test Mol Biomarkers 23: 618-633, 2019.

6. Ebersole JL, Lambert J, Bush H, Huja PE and Basu AJN: Serum nutrient levels and aging effects on periodontitis. Nutrients 10 : 1986, 2018.

7. Suchanecka A, Chmielowiec K, Chmielowiec J, Trybek G Masiak J, Michałowska-Sawczyn M, Nowicka R, Grocholewicz K and Grzywacz A: Vitamin D receptor gene polymorphisms and cigarette smoking impact on oral health: A case-control study. Int J Environ Res Public Health 17: 3192, 2020.

8. Toy V and Uslu MO: Do genetic polymorphisms affect susceptibility to periodontal disease? A literature review. Niger J Clin Pract 22: 445-453, 2019

9. Nikolopoulos GK, Dimou NL, Hamodrakas SJ and Bagos PG: Cytokine gene polymorphisms in periodontal disease: A meta-analysis of 53 studies including 4178 cases and 4590 controls. J Clin Periodontol 35: 754-767, 2008.

10. Soga Y, Nishimura F, Ohyama H, Maeda H, Takashiba S and Murayama Y: Tumor necrosis factor-alpha gene (TNF-alpha)-1031/-863,-857 single-nucleotide polymorphisms (SNPs) are associated with severe adult periodontitis in Japanese. J Clin Periodonto 30: 524-531, 2003.
11. Koutouzis T, Haber D, Shaddox L, Aukhil I and Wallet SM: Autoreactivity of serum immunoglobulin to periodontal tissue components: A pilot study. J Periodontol 80: 625-633, 2009.

12. Holla LI, Fassmann A, Augustin P, Halabala T, Znojil V and Vanek J: The association of interleukin-4 haplotypes with chronic periodontitis in a Czech population. J Periodontol 79: 1927-1933, 2008.

13. Donati M, Berglundh T, Hytönen AM, Hahn-Zoric M, Hanson LA and Padyukov L: Association of the- 159 CD14 gene polymorphism and lack of association of the- 308 TNFA and Q551R IL-4RA polymorphisms with severe chronic periodontitis in Swedish Caucasians. J Clin Periodontol 32: 474-479, 2005.

14. van Sorge NM, van der Pol WL and van de Winkel JG: FcgammaR polymorphisms: Implications for function, disease susceptibility and immunotherapy. Tiss Antigens 61: 189-202, 2003.

15. LeVan TD, Bloom JW, Bailey TJ, Karp CL, Halonen M, Martinez FD and Vercelli D: A common single nucleotide polymorphism in the CD14 promoter decreases the affinity of Sp protein binding and enhances transcriptional activity. J Immunol 167: 5838-5844, 2001.

16. Selvaraj P, Chandra G, Jawahar M, Rani MV, Rajeshwari DN and Narayanan PR: Regulatory role of vitamin D receptor gene variants of Bsm I, Apa I, Taq I, and Fok I polymorphisms on macrophage phagocytosis and lymphoproliferative response to mycobacterium tuberculosis antigen in pulmonary tuberculosis. J Clin Immunol 24: 523-532, 2004.

17. Gelder CM, Hart KW, Williams OM, Lyons E, Welsh KI, Campbell IA and Marshall SE: Vitamin D receptor gene polymorphisms and susceptibility to Mycobacterium malmoense pulmonary disease. J Infect Dis 181: 2099-2102, 2000.

18. Banjabi AA, Al-Ghafari AB, Kumosani TA, Kannan K and Fallatah SM: Genetic influence of vitamin D receptor gene polymorphisms on osteoporosis risk. Int J Health Sci (Qassim) 14: 22-28, 2020.

19. Guo HX, Pan J, Pan HB, Cui SJ and Fang CY: Correlation of vitamin D receptor gene (ApaI) polymorphism with periodontitis: A meta-analysis of Chinese population. Food Sci Nutr 7: 3607-3612, 2019.

20. Gunes S, Sumer AP, Keles GC, Kara N, Koprulu H, Bagci H and Bek Y: Analysis of vitamin D receptor gene polymorphisms in patients with chronic periodontitis. Indian J Med Res 127: 58-64, 2008.

21. Laine ML, Loos BG and Crielaard W: Gene polymorphisms in chronic periodontitis. Int J Dent 2010: 324719, 2010.

22. Perić M, Cavalier E, Toma S and Lasserre J: Serum vitamin D levels and chronic periodontitis in adult, Caucasian population-a systematic review. J Periodontal Res 53: 645-656, 2018.

23. Uwitonze AM, Murererehe J, Ineza MC, Harelimana EI, Nsabimana U, Uwambaye P, Gatarayiha A and Haq A: Effects of vitamin D status on oral health. J Steroid Biochem Mol Biol 175: 190-194, 2018.

24. World Medical Association: World medical association declaration of helsinki: Ethical principles for medical research involving human subjects. JAMA 310: 2191-2194, 2013.

25. Tachi Y, Shimpuku H, Nosaka Y, Kawamura T, Shinohara M, Ueda M, Imai H and Ohura K: Vitamin D receptor gene polymorphism is associated with chronic periodontitis. Life Sci 73: 3313-3321, 2003.

26. de Brito Júnior RB, Scarel-Caminaga RM, Trevilatto PC, Souza AP and Barros SP: Polymorphisms in the vitamin $\mathrm{D}$ receptor gene are associated with periodontal disease. J Periodontol 75: 1090-1095, 2004.

27. Tonetti MS, Greenwell $\mathrm{H}$ and Kornman KS: Staging and grading of periodontitis: Framework and proposal of a new classification and case definition. J Periodontol 89 (Suppl 1): S159-S172, 2018.

28. Lertpimonchai A, Rattanasiri S, Arj-Ong Vallibhakara S, Attia J and Thakkinstian A: The association between oral hygiene and periodontitis: A systematic review and meta-analysis. Int Dent J 67: 332-343, 2017.

29. Greene JC and Vermillion JR: The simplified oral hygiene index. J Am Dent Assoc 68: 7-13, 1964.

30. Boom R, Sol CJ, Salimans MM, Jansen CL, Wertheim-van Dillen PM and van der Noordaa J: Rapid and simple method for purification of nucleic acids. J Clin Microbiol 28: 495-503, 1990.

31. Williams KR, Wasson SR, Barrett A, Greenall RF, Jones SR and Bailey EG: Teaching hardy-weinberg equilibrium using population-level punnett squares: Facilitating calculation for students with math anxiety. CBE-Life Sciences Education 20: ar22, 2021. 
32. Hamrun $\mathrm{N}$ and Hatta M: Polymorphisms of Vitamin D receptor gene in chronic periodontitis patients [Indonesia]. JST Kesehatan 1: 165-172, 2011.

33. Hamrun N: Polymorphism of Vitamin D receptor gene is associated with chronic periodontitis [Indonesia]. Dentika: Dental J 16: 121-125, 2011.

34. Mashhadiabbas F, Neamatzadeh H, Nasiri R, Foroughi E, Farahnak S, Piroozmand P, Mazaheri M and Zare-Shehneh M: Association of vitamin D receptor BsmI, TaqI, FokI, and ApaI polymorphisms with susceptibility of chronic periodontitis: A systematic review and meta-analysis based on 38 case -control studies. Dent Res J (Isfahan) 15: 155-165, 2018.

35. Ho YP, Lin YC, Yang YH, Chou YH, Ho KY, Wu YM and Tsai CC: Association of vitamin D receptor gene polymorphisms and periodontitis in a Taiwanese Han population. J Dent Sci 12: 360-367, 2017.

36. Loos BG, John RP and Laine ML: Identification of genetic risk factors for periodontitis and possible mechanisms of action. J Clin Periodontol 32: 159-169, 2005.

37. Sun J, Meng H, Cao C, Tachi Y, Shinohara M, Ueda M, Imai H and Ohura K: Relationship between vitamin D receptor gene polymorphism and periodontitis. J Periodontal Res 37: 263-267, 2002.

38. Divaris K, Monda KL, North KE, Olshan AF, Reynolds LM, Hsueh WC, Lange EM, Moss K, Barros SP, Weyant RJ, et al: Exploring the genetic basis of chronic periodontitis: A genome-wide association study. Hum Mol Genet 22: 2312-2314, 2013.

39. Zmuda JM, Cauley JA and Ferrell R: Molecular epidemiology of vitamin D receptor gene variants. Epidemiol Rev 22: 203-207, 2000.

40. Wang C, Zhao H, Xiao L, Xie C, Fan W, Sun S, Xie B and Zhang J: Association between vitamin D receptor gene polymorphisms and severe chronic periodontitis in a Chinese population. J Periodontol 80: 603-608, 2009.

41. Naito M, Miyaki K, Naito T, Zhang L, Hoshi K, Hara A Masaki K, Tohyama S, Muramatsu M, Hamajima N and Nakayama T: Association between vitamin D receptor gene haplotypes and chronic periodontitis among Japanese men. Int J Med Sci 4: 216-222, 2007.
42. Uitterlinden AG, Fang Y, Van-Meurs JB, Pols HA and Van-Leeuwen J: Genetics and biology of vitamin D receptor polymorphisms. Gene 338: 143-156, 2004.

43. Marian D, Rusu D, Stratul SI, Calniceanu H, Sculean A and Anghel A: Association of vitamin D receptor gene polymorphisms with chronic periodontitis in a population in Western Romania. Oral Health Prev Dent 17: 157-165, 2019.

44. Jilani M, Mohamed AA, Zeglam HB, Alhudiri IM, Ramadan AM, Saleh SS, Elkabir M, Amer IB, Ashammakhi N and Enattah NS: Association between vitamin D receptor gene polymorphisms and chronic periodontitis among Libyans. Libyan J Med 10: 26771, 2015.

45. Borges MA, Figueiredo LC, Brito RB Jr, Faveri M and Feres M: Microbiological composition associated with vitamin D receptor gene polymorphism in chronic periodontitis. Braz Oral Res 23: 203-208, 2009.

46. Brett P, Zygogianni P, Griffiths G, Tomaz M, Parkar M, D'Aiuto F and Tonetti M: Functional gene polymorphisms in aggressive and chronic periodontitis. J Dent Res 84: 1149-1153, 2005.

47. Kuo LC, Polson AM and Kang T: Associations between periodontal diseases and systemic diseases: A review of the inter-relationships and interactions with diabetes, respiratory diseases, cardiovascular diseases and osteoporosis. Public Health 122: 417-433, 2008.

48. Amano Y, Komiyama K and Makishima MJ: Vitamin D and periodontal disease. J Oral Sci 51: 11-20, 2009.

49. Ruiz-Ballesteros AI, Meza-Meza MR, Vizmanos-Lamotte B, Parra-Rojas I and de la Cruz-Mosso U: Association of vitamin D metabolism gene polymorphisms with autoimmunity: Evidence in population genetic studies. Int J Mol Sci 21: 9626, 2020.

This work is licensed under a Creative Commons Attribution-NonCommercial-NoDerivatives 4.0 International (CC BY-NC-ND 4.0) License. 